\title{
Pengenalan Covid-19 pada Anak Usia Prasekolah: Analisis pada Pelaksanaan Peran Orangtua di Rumah
}

\author{
Rohita \\ Pendidikan Guru Pendidikan Anak Usia Dini, Universitas Al-Azhar Jakarta \\ DOI: $\underline{10.31004 / o b s e s i . v 5 i 1.528}$
}

\begin{abstract}
Abstrak
Penelitian ini bertujuan untuk menggambarkan dan menganalisis pelaksanaan peran orangtua dalam mengenalkan virus corona pada anak prasekolah. Metode penelitian menggunakan kualitatif dengan pendekatan deskriptif. Subjek penelitian berjumlah lima keluarga yang memiliki anak usia prasekolah. Penentuan subjek menggunakan teknik purposive sampling yaitu dengan kriteria keluarga yang memiliki anak usia pra sekolah yaitu usia 3-6 tahun dan berlokasi di RT 006 RW 07, Perum 2, Tangerang, Banten. Pengumpulan data dilakukan dengan metode wawancara, observasi, dan dokumentasi. Analisis data menggunakan model Miles and Huberman dengan tahap pengumpulan data, reduksi data, display data, dan ferivikasi data. Kesimpulan dari penelitian ini adalahorangtua telah melaksanakan perannya dalam mengenalkan Covid-19 menggunakan media TV, HP dan youtube; menjadi contoh dalam tindakan pencegahan;serta mengajarkan berbagai tindakan pencegahan dengan pendampingan, penjelasan, serta bujukan dan rayuan terutama bagi anak yang sulit untuk melaksanakan tindakan perlindungan diri dari Covid-19. Namun, pengenalan Covid-19 lebih banyak dilakukan ibu dibandingkan ayah. Sehingga diperlukan kerjasama dan peran ayah untuk mendukung dan melengkapi usaha yang dilakukan ibu dalam mengenalkan Covid-19 kepada anak.
\end{abstract}

Kata kunci: covid-19; peran orangtua; anak usia prasekolah

\begin{abstract}
This study aims to describe and analyze the implementation of the role of parents in introducing the corona virus in preschool children. The research method uses qualitative descriptive approach. Research subjects numbered five families who have preschool-aged children. Determination of the subject using a purposive sampling technique that is the criteria of families who have pre-school age children that are aged 3-6 years and located in RT 006 RW 07, Perum 2, Tangerang, Banten. Data collection is done by interview, observation and documentation. Data analysis using the Miles and Huberman model with the stages of data collection, data reduction, data display, and data fermentation. The conclusion of this research is that parents have carried out their role in introducing Covid-19 using TV, cellphone and youtube media; be an example in preventive action; and teach various preventive actions with assistance, explanations, as well as persuasion and persuasion especially for children who find it difficult to carry out self-protection measures from Covid-19. However, the introduction of Covid-19 is done more by mothers than fathers. So that collaboration and the role of fathers are needed to support and complete the efforts made by mothers in introducing Covid-19 to children.
\end{abstract}

Keywords: covid-19; the role of parents; preschool age children

Copyright (c) 2020 Rohita

$\square$ Corresponding author:

Email Address : rohita@uai.ac.id (Jakarta, Indonesia)

Received 3 may 2020, Accepted 6 June 2020, Published 12 June 2020 


\section{PENDAHULUAN}

Berita mengenai virus corona atau yang dikenal juga dengan nama Covid-19(Corona Virus Deseas-19) telah menjadi konsumsi harian masyarakat Indonesia, bahkan banyak Negara di dunia, sejak diumumkannya virus corona sebagai pandemic global. Statuspandemic global disampaikan Direktur Jenderal Tedros Adhanom Ghebreyesus dari organisasi kesehatan dunia (WHO) setelah jumlah infeksi di seluruh dunia mencapai lebih dari 121.000 kasus(Utomo, 2020).Berdasarkan data terakhir yang terdapat dalam website WHO, hingga 30 April 2020, terdapat 3.090.445 terkonfirmasi, 217.769 mengalami kematian, dan 213 negara, area atau territory terdampak Covid-19 (World Health Organization, 2020).Sementara di Indonesia sendiri, data terakhir pada 30 April 2020 diketahui 10.118 positif, 792 meninggal, dan 1.522 sembuh, dengan urutan terbanyak di Pulau Jawa secara berurutan yaitu Jakarta, Jawa Barat, Jawa Timur, dan Jawa Tengah (Cnnindonesia, 2020).

Covid-19 adalah penyakit menular yang disebabkan oleh jenis corona virus yang baru ditemukan, yang pertama kali terjadi di Wuhan, Tiongkok, bulan Desember 2019.Adapun gejala Covid-19 yang paling umum adalah demam, rasa lelah, dan batuk kering, rasa nyeri sakit, hidung tersumbat, pilek, sakit tenggorokan atau diare. Covid-19 dapat menyebar dari orang ke orang melalui percikan-percikan dari hidung atau mulut yang keluar saat orang yang terjangkit Covid-19 batuk atau mengeluarkan napas. Percikan yang keluar tersebut akan jatuh dan mengenai benda serta permukaan lain di sekitarnya. Apabila benda atau permukaan tersebut disentuh atau tersentuh tangan, kemudiantangan tersebut menyentuh mata, hidung atau mulutnya, maka orang tersebut akan terjangkit Covid-19. Pemerintah dalam hal ini kementerian kesehatan telah mengeluarkan pedoman tindakan pencegahan Covid-19, yaitu menjaga kebersihan diri dan rumah dengan cara: a. Mencuci tangan dengan sabun setidaknya 20 detik atau menggunakan hand sanitizer; b. Hindari menyentuh mata, hidung, dan mulut dengan tangan yang belum dicuci; c. Tidak berjabat tangan; d. Hindari interaksi fisik dekat dengan orang yang memiliki gejala sakit; e. Menutup mulut saat batuk dan bersin dengan lengan atas bagian dalam atau dengan tisu, membuang tisu, dan segera cuci tangan; f. Segera mengganti baju/mandi setelah berpergian; g. menyemprotkan desinfektan secara berkala pada benda-benda terutama yang sering disentuh, seperti gagang pintu, dan lainnya((Indonesia, 2020).Guna mencegah lebih banyak penularan dari virus tersebut serta untuk melindungi masyarakat, pemerintah menerapkan kebijakan pembatasan sosial berskala besar (PSBB).Penyebaran Covid-19 dan pemberlakuan PSBB memberikan dampak sangat luas pada berbagai aspek kehidupan masyarakat, baik kesehatan, ekonomi, sosial budaya, politik hukum, dan termasuk juga pendidikan, mulai dari perguruan tinggi hingga pendidikan pada level terendah, yaitu pendidikan anak usia dini.

Pendidikan anak usia dini adalah suatu upaya yang diberikan orang dewasa kepada anak sejak lahir hingga usia 6 tahun dengan berbagai stimulasi untuk membantu pertumbuhan dan perkembangannya secara optimal. Mulai usia 2 atau 3 tahun hingga 6 tahun anak mulai mengenal lingkungan lain di luar keluarganya yaitu lingkungan sekolah, baik kelompok bermain maupun taman kanak-kanak atau lembaga pendidikan sejenis lainnya. Di dalam lingkungan tersebut anak melakukan berbagai aktivitas terstruktur, sistematis, dan bertujuan yang telah disiapkan guru di sekolah. Berbagai variasi kegiatan dilakukan termasuk pembiasaan-pembiasaan untuk menanamkan nilai agama dan pembentukan karakter anak. Di lembaga tersebut pula anak mengenal dirinya, temannya, orang dewasa di sekitarnya, serta lingkungannya. Berbagai permasalahan yang dialami juga menjadi stimulus dalam rangka meningkatkan kemampuan-kemampuan anak. Namun, dengan adanya PSBB berbagai aktivitas rutin yang dilakukan anak selama di sekolah tidak dapat dilakukan. Menyusul dikeluarkannya Surat Edaran Dinas Pendidikan Provinsi DKI Jakarta (Jakarta, 2020) mengenai Pembelajaran Jarak Jauh, yang diikuti oleh sebagian besar provinsi di Indonesia. Akibatnya, stimulasi dan pendampingan pembelajaran yang biasanya diberikan guru di sekolah kini bergeser kepada orangtua di rumah. 
Pada dasarnya tugas mendidik tetaplah menjadi kewajiban orangtua, meskipun anak telah berada pada usia prasekolah, maupun usia sekolah, dari jenjang pendidikan terendah hingga pendidikan tinggi. Terlebih di masa pandemik global seperti saat ini. Sebagai pendidik, tentunya orangtua harus bisa melaksanakan perannya untuk memberikan berbagai hal yang dapat meningkatkan pengetahuan, kemampuan, dan keterampilan anak, serta menjamin kesehatan anak-anaknya. Seperti yang dituliskan Ceka dan Murati: “...the family has a huge and very tough responsibility; as it has to take proper care on their health, their physical development, their overall education, the development of their intellectual affinities, as well as creation for a better moral values and convictions and attitudes, habits to a firm and well behaved cultural relations in the family itself as well as in the society where the child lives."(Marui, 1952)

Namun, pelaksanaan peran orangtua tergantung bagaimana orangtua memandang peran tersebut, cara melaksanakannya (Lestari sri, 2018), serta pengetahuan bahwaorang tua memiliki kewajiban dan tanggung jawab untuk mengasuh, memelihara, mendidik, dan melindungi anak(Hadi, 2016).Bahkan lebih dari itu, orangtua harus memahami bahwaorangtua adalah the ones who shape the child's personality, offer the child role-models and benchmarks. The interaction between parents and children is an indispensable factor for the normal development of the child, the family being a communication system and development environment of the child from the earliest years(Marilena, 2015). Orangtua adalah pembentuk kepribadian anak, sehingga orangtua harus dapat menjadi teladan bagi anak-anaknya, terlebih pada masa anak memasuki usia prasekolah. Menurut Vasilyevaa dan Shcherbakovb, "Preschool childhood is an important period in the formation of a child's personality, determining its future development prospects. That as elements of the parent-child relationship structure parental relationships and functional parental roles have a significant impact on the emotional and personal well-being of a preschooler."(Vasilyeva \& Shcherbakov, 2016)

Orangtuayang terdiri dari ayah dan ibu, memiliki pembagian peran yang cukup jelas namun saling melengkapi.Ayah berperan sebagai pencari nafkah, pendidik, pelindung dan pemberi rasa aman, serta sebagai kepala keluarga(Aisyah, Riana, \& Putri, 2019; Jailani, 2014; R \& R, 2010).Ayah juga bertugas untuk mengorganisasikan dan memfungsikan rumah tangganya, serta menghadirkan rasa aman dalam kehidupan seluruh anggota keluarganya (Marui, 1952).Temuan mengenai rata-rata waktu yang digunakan ayah dalam berinteraksi dengan anak adalah 6 jam. Secara kuantitas,jumlah tersebut cukup memadai untuk digunakan ayah melakukan aktivitas bersama dengan anaknya(Hidayati, Kaloeti, \& Karyono, 2011).Keterlibatan ayah dalam pengasuhan secara langsung, teraktur, dan aktif berdampak positif terhadap perkembangan kognitif, emosional, dan sosial (Lismanda, 2017). Adapun ibu berperan sebagai pengurus rumah tangga, pelindung, pengasuh, dan pendidik anak-anaknya(R \& R, 2010). Sebagai pelindung, ibu memiliki dua fungsi yaitu memberikan perlindungan secara fisik yang meliputi pemberian perawatan kesehatan serta memberikan kondisi yang bersih, serta perlindungan secara psikologis dimana ibu harus dapat memberikan keamanan secara emosional maupun kejiwaan kepada anak(Marui, 1952). Adanya kedekatan emosional antara ibu dengan anaknya memudahkan bagi ibu untuk melakukan pendampingan yang merupakan salah satu dasar penting bagi keberhasilan anak baik secara akademik, maupun afektif, dan konatif (Abtokhi, 2012). Seorang ibu juga harus menjadi teladan bagi anak-anaknya, termasuk penggunaan bahasa yang akan ditiru anak dan digunakan anak dalam kesehariannya (Gade, 2012). Apabila ibu dapat menjalankan perannya dengan baik maka anak akan memiliki konsep diri yang baik (Pangesti \& Agussafutri, 2017).

Keberhasilan ayah dan ibu dalam menjalankan perannya tentu akan berdampak positif pada anak, baik anak sebagai individu, anggota keluarga, maupun anggota masyarakat(Marui, 1952).Untuk dapat menjalankan perannya dengan baik, orangtua memerlukan pendidikan dalam tingkat yang cukup tinggi, sehingga orangtua memiliki cukup banyak pengetahuan, pemahaman, dan kemampuan untuk mendidik anak-anaknya dengan cara yang benar. Pengetahuan dan pemahaman orangtua akan pentingnya pendidikan membuat anak memiliki pemikiran yang sama dengan orangtuanya. Matilov 
dan Naum dalam Ceka \& Murati menuliskan bahwa educational level of children in the family depends more on the level of the parent's education, so this factor strongly affects family relationships and the successful development of children(Marui, 1952).Ditambahkan pula oleh Kasapi dan Gjylymsere dalam Marilena bahwa Children always adopt parent's values and types of behavior (Marilena, 2015)

Pengetahuan yang dimiliki orangtua juga memberikan dampak pada keberhasilan stimulus yang diberikan. Hasil penelitian Handayani, Samiasih, dan Mariyam menemukan bahwa ada hubungan bermakna tingkat pengetahuan orang tua tentang stimulasi verbal dengan perkembangan bahasa anak prasekolah di TK PGRI 116 Bangetayu Wetan(Kosegeran, Ismanto, \& Babakal, 2013). Ditemukan pula hubungan yang signifikan antara pengetahuan dan peran orang tua dengan perilaku hidup bersih dan sehat(Wulandari \& Pertiwi, 2018).Demikian pula dengan pengetahuan dan pemahaman mengenai Covid-19 yang dimiliki orangtua tentu akan berdampak pada pengetahuan dan pemahaman anak mengenai hal tersebut serta kemauan untuk melakukan tindakan-tindakan pencegahannya. Seperti misalnya pembiasaan mencuci tangan.Pengetahuan orangtua, baik ayah maupun ibu mengenai pentingnya mencuci tangan, tidak hanya harus diajarkan kepada anak-anaknya, tetapi orangtua juga harus melakukan kegiatan tersebut. Sehingga anak tidak hanya mendengar perintah orangtua tetapi juga melihat orangtuanya melakukan kegiatan mencuci tangan.Banyak penelitian menemukan keberhasilan pelaksanaan suatu kepada anak usia dini karena adanya keterlibatan orangtua. Beberapa hasil penelitian menemukan hubungan yang bermakna antara peran ayah dengan kebiasaan mencuci tangan (Hastuti, Aisah, \& Santosa, 2011; Rihiantoro \& Jurusan Keperawatan Poltekkes Tanjungkarang, 2016).Semakin jelas, pentingnya pengetahuan, kemauan melakukannya, serta kemauan melibatkan diri dalam berbagai aktivitas anak, terlebih disaat pandemic Covid-19.Diantaranya, penelitian yang dilakukan Rihiantoro, 2016; dan, Hastuti, Aisah, Santoso, 2011, yang menemukan bahwa terdapat

Tentunya upaya pencegahan Covid-19 seperti telah disampaikan diawal bukan saja hanya sebatas mencuci tangan. Orangtua dapat mengetahui berbagai informasi mengenai hal tersebutdengan berbagai cara dan dari bermacam media.Media massa memiliki posisi yang penting dalam kehidupan masyarakat, yang diantaranya adalah mempengaruhi khalayak melalui pesan berupa informasi, hiburan, pendidikan maupun pesan-pesan lainnya (Khatimah, 2018). Televisi juga menjadi salah satu media yang digunakan untuk menyebarkan berbagai informasi, termasuk informasi kesehatan terkait virus corona. Dampak yang ditimbulkan cukup besar. Hasil penelitian yang ditemukan Dadan, diketahui bahwa penayangan informasi kesehatan melalui televisi berpengaruh terhadap sikap Ibu-ibu rumah tangga mengenai hidup sehat dalam keluarga(Mulyana, 2002).

Selain media massa dan televisi, terdapat media lainnya yaitu media sosial dan gadget berupa HP. Dampak positif dari media sosial diantaranya adalah memudahkan untuk berinteraksi dengan banyak orang, memperluas pergaulan, mendekatkan jarak dan waktu, tempat mengekspresikan diri, serta mempercepat penyebaran informasi dengan biaya yang lebih murah(Cahyono, 2016).Dampak positif media sosial juga didapatkan anak usia dini, berupa peningkatan semua aspek perkembangannya sehingga anak menjadi lebih komunikatif, imaginatif, dan aktif(Rohani, 2015). Adapun gadget merupakan perangkat elektronik kecil yang memiliki fungsi khusus di setiap jenis nya untuk memudahkan pekerjaan dan kebutuhan manusia menjadi lebih praktis dan efisien (Putra, 2017). Demikian pula dengan youtube sebagai salah satu sarana penyebaran informasi yang dapat diakses melalui HP selama masih memiliki kuota cukup. Terkait dengan media Youtube, jika dibandingkan dengan kekurangannya, Faiqah, Nadjib, dan Amir menyatakan bahwa pemanfaatan yang dirasakan oleh penggunanya, berdasarkan masing-masing kebutuhan pengguna lebih condong pada kelebihannya,membuat youtube ternilai sangat efektif dan efisien sebagai sarana komunikasi bagi komunitas.(Fatty Faiqah, . Muh. Nadjib, . Andi Subhan Amir, 2016).Di dalam pendidikan, youtube dapat dimanfaatkan sebagai media ajar 
untuk meningkatkan minat belajar serta motivasi belajar mahasiswa(Mujianto, 2019) serta salah satu sarana komunikasi dakwah oleh para dai(Hajar, 2018). Sementara pada anak prasekolah, penggunaan youtube dapat pula memberikan dampak positif dimana stimulasi yang terdapat di dalamnya dapat meningkatkan perhatian dan konsentrasi, rasa ingin tahu, daya ingat, imajinasi, kreativitas, dan bahasa (Khoiriyati \& Saripah, 2018), serta increase intellectual, emotional, spiritual, and social intelligence (Palupi, 2020). Berdasarkan beberapa hasil penelitian tersebut, maka dapat dikatakan bahwa TV, HP, youtube, media sosial tidak hanya dapat digunakan dan bermanfaat bagi orang dewasa pada umumnya, tetapi juga mahasiswa hingga anak usia dini, komunitas, dai, hingga ibu rumah tangga.

Namun, beredarnya informasi yang disajikan melalui berbagai media tersebut akan lebih mudah dipahami anak apabila orangtua mampu menjelaskan sesuai dengan tingkat kemampuan berfikir anak. Berdasarkan padangan Jean Piaget, anak usia 2-7 berada pada taraf berpikir praoperasional, sehingga diperlukansuatu strategi dalam usaha memahamkannya. Hewi dan Asnawati menuliskan bahwa anak dapat diajak berpikir dengan mengajukan pertanyaan-pertanyaan mengapa sekolah di rumah, mengapa keluar rumah harus menggunakan masker, kenapa tidak bisa bermain di luar rumah dengan menggunakan metode dialog (percapakan /diskusi), tentunya disertai dengan keteladanan dari orangtua(Hewi \& Asnawati, 2020). Sehingga anak dapat menerima kondisi yang ada saat ini dengan penerimaan yang baik, mau mengikuti apa yang diharapkan orangtua dan tetap mendapatkan stimulus untuk mendukung tumbuh kembangnya.

Berdasarkan paparan tersebut, maka tujuan penelitian ini adalah untuk menggambarkan pelaksanaan peran orangtua dalam mengenalkan Covid-19 pada anak usia prasekolah di rumah.

\section{METODOLOGI}

Metode yang digunakan dalam penelitian ini adalah metode dengan desain deskriptif kualitatif yang bertujuan untuk menggambarkan, meringkaskan berbagai kondisi, berbagai situasi, atau berbagai fenomena realitas sosial yang ada di masyarakat yang menjadi objek penelitian, dan berupaya menarik realitas itu ke permukaan sebagai suatu ciri, karakter, sifat, model, tanda, atau gambaran tentang kondisi, situasi, ataupun fenomena tertentu (Bungin, 2011). Subjek penelitian adalah lima keluarga di wilayah RT 006 RW 07, Perum II, Tangerang, Banten yang memiliki anak usia prasekolah, terdiri dari 3 orang anak laki-laki, dan 2 orang anak perempuan. Teknik penentuan subjek menggunakan purposive sampling, yaitu menentukan keluarga dengan anak usia 3-6 tahun. Pengumpulan data dilakukan dengan menyebarkan kuesioner, dokumentasi, dan observasi. Penentuan lokasi serta teknik penyebaran kuesioner dilakukan dengan mempertimbangkan lokasi tempat tinggal peneliti serta mengikuti aturan pemerintah terkait PSBB, social distancing, dan anjuran stay at home.Kisi-kisi kuesioner mencakup pertanyaan apa, siapa, dan bagaimana terkait Covid-19. Analisis data dilakukan menggunakan model Miles and Huberman, yang mencakup tahapreduksi data, display data, dan verification data. Penyajian data dilakukan dengan menampilkan tabel, diagram, dan narasi untuk memperkuat pemahaman. Berikut gambar desain penelitian yang dilakukan.

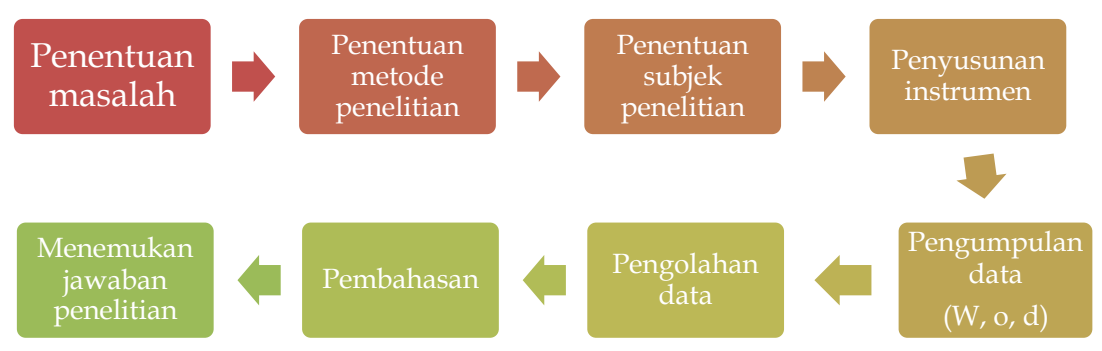

Gambar 1. desain penelitian 


\section{HASIL DAN PEMBAHASAN}

Perum (perumahan umum) II khususnya RT 006 RW 07 Tangerang, Banten merupakan suatu perumahan yang sebagian besar dihuni oleh keluarga pensiunan. Tidak banyak keluarga muda dengan anak usia prasekolah yang tinggal di sana. Dari 25 kepala keluarga, hanya terdapat enam keluarga yang memiliki anak usia dini, namun satu diantaranya keluarga dengan anak usia 2 tahun. Artinya dari 6 kepala keluarga dengan anak usia dini, hanya 5 keluarga yang dapat dijadikan subjek penelitian, yaitu keluarga dengan anak usia 3-6 tahun. Adapun pembagiannya terdiri dari 1 keluarga dengan anak usia 3 tahun (laki-laki), 2 keluarga dengan anak usia 5 tahun (lk dan pr), dan 2 keluarga dengan anak usia 6 tahun (lk dan pr).

Berdasarkan hasil kuesioner yang diberikan kepada lima keluarga tersebut, diperoleh jawaban yang bervariasi mengenai pengertian virus Corona dan penyebabnya. Diantaranya, memberikan jawaban bahwa virus corona adalah virus yang menyerang dan menyebabkan infeksi saluran pernapasan; infeksi paru-paru hingga kematian; virus baru yang menular ke manusia dan menyerang lansia atau siapa saja mulai dari bayi, anak, dewasa, ibu hamil, dan menyusui; penyakit menular yang disebabkan oleh virus jenis baru yang belum pernah terindentifikasi pada manusia; dan virus yang dapat menyebar dengan cepat dan mematikan, sangat membahayakan. Namun, informasi mengenai penyebab munculnya virus corona yang diberikan orangtua terlihat masih simpang siur. Jawaban yang diberikan adalah virus yang terinfeksi dari binatang; merupakan wabah pandemi, tertular secara cepat; penyakit yang ditimbulkan oleh infeksi virus corona baru; kurang bersih; hubungan dengan orang yang sakit corona, kurang menjaga kebersihan, serta kurang menjaga stamina tubuh.

Mengenai gejala yang dialami seseorang yang terkena virus corona, serta tindakan pencegahan yang disarankan kementerian kesehatan, responden memberikan jawaban seperti tertera dalam diagram berikut.

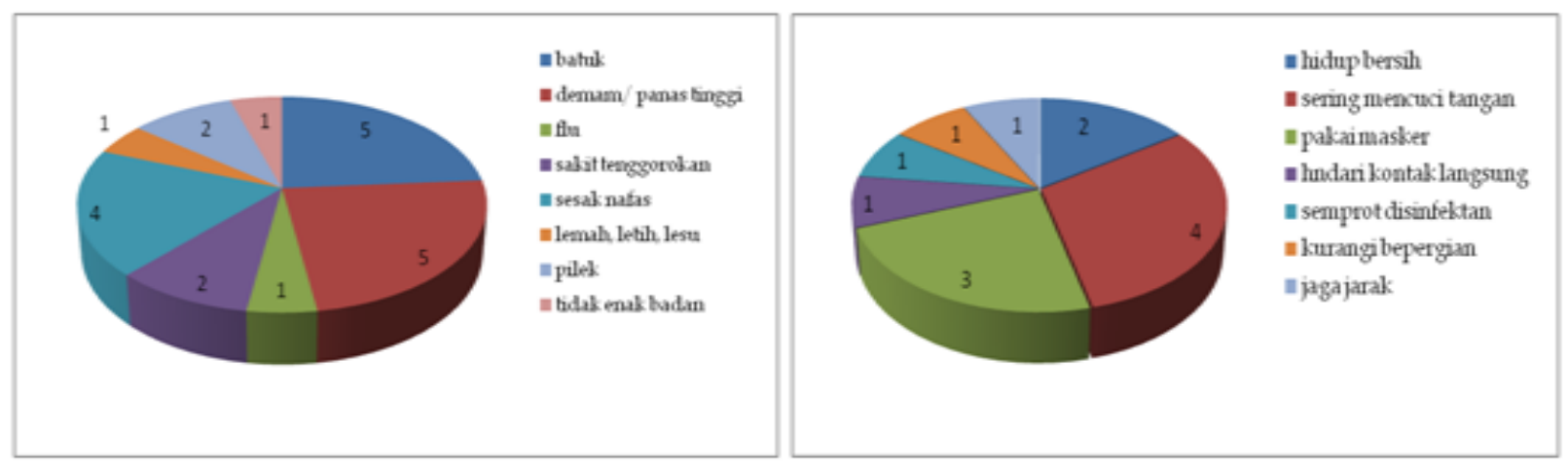

Gambar 2. Gejala virus corona (kiri); tindakan pencegahan (kanan)

Berdasarkan gambar 2, terlihat bahwa responden memberikan jawaban mengenai gejala terkena virus Corona serta tindakan pencegahannya. Apabila dibandingkan dengan gejala dan tindakan yang ditunjukkan oleh kementerian kesehatan (Indonesia, 2020)maupun WHO, jawaban tersebut tidaklah jauh berbeda. Sehingga dapat dikatakan bahwa orangtua telah memiliki pengetahuan yang cukup mengenai gejala dan tindakan pencegahan dari Covid-19.Pengetahuan merupakan hal yang perlu dimiliki oleh siapapun terutama orangtua sebagai pemimpin dalam keluarga yang bertanggungjawab atas semua keadaan anggota keluarga di dalamnya. Adanya pengetahuan menjadi dasar dimilikinya pemahaman yang kuat untuk dapat menerapkan perilaku-perilaku yang baik sesuai dengan pengetahuan yang dimilikinya. Selanjutnya, dapat memberikan keyakinan dan kemampuan bagi orangtua untuk dapat menjalankan perannya membentuk perilaku hidup bersih dan sehat (Wulandari \& Pertiwi, 2018). Orangtua yang terdiri dari ayah dan ibu harus dapat melaksanakan perannya masing-masing untuk menjamin kesejahteraan anak-anaknya termasuk dalam hal 
kesehatan(Marui, 1952).Pengetahuan tersebut diperoleh orangtua melalui berita-berita yang ditayangkan di TV, informasi yang diperoleh dari HP melalui sosial media, maupun youtube. Adanya informasi yang disebarkan secara masif mengenai Covid-19, bahaya, serta pencegahannya memberikan pemahaman kepada orangtua agar mereka beserta anggota keluarganya dapat terhindar dari bahaya Covid-19 yang kemudian mempengaruhi sikap orangtua mengenai perilaku agar dapat hidup sehat(Mulyana, 2002). Perilaku sehat terutama berkaitan dengan pencegahan Covid-19 terlihat dari jawaban yang diberikan orangtua berikut ini.

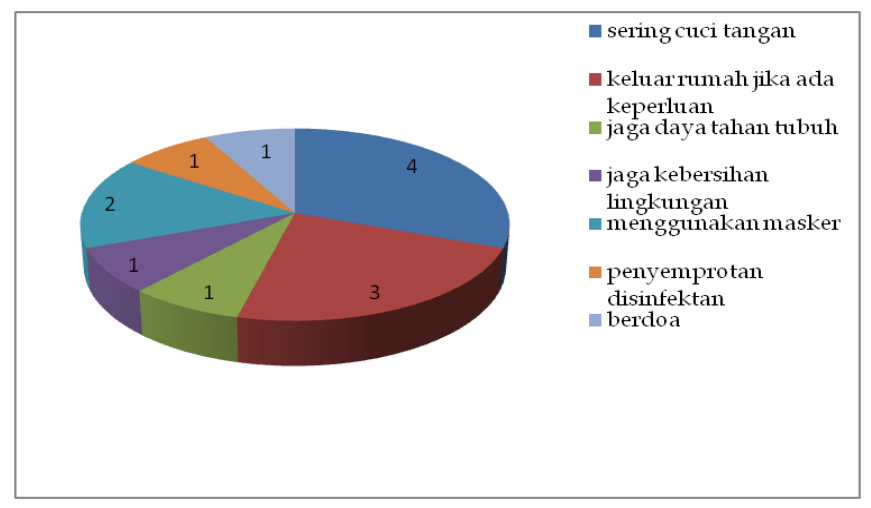

Gambar 3. Tindakan yang dilakukan orangtua

Berdasarkan gambar 3, terlihat bahwa tindakan yang banyak dilakukan orangtua untuk mencegah diri dan keluarganya dari virus corona adalah sering mencuci tangan, tetap berada di rumah, serta menggunakan masker jika bepergian. Hal tersebut dapat dimaknai bahwa setelah orangtua mengetahui mengenai bahaya Covid-19 dan upaya yang harus dilakukan agar terhindar dari virus tersebut, maka orangtua melakukan tindakan-tindakan yang dianjurkan.Hal tersebut juga membuktikan bahwa adanya tindakan karena adanya pemahaman dan pengetahuan yang telah dimilikinya. Karena tidak mungkin seseorang akan melakukan sesuatu apabila ia tidak tahu apa dan untuk apa sesuatu perlu dilakukan. Untuk dapat mencegah diri dan keluarganya dari penularan Covid-19, orangtua tentu juga harus menjelaskan masalah yang ada kepada anak-anaknya. Di dalam proses penyampaiannya, mungkin orangtua mengalami kesulitan untuk menjelaskan hal-hal yang tidak mudah dipahami anak. Mengingat anak usia 3-6 tahun berada pada tahap berpikir praoperasional sementara berbicara mengenai sebuah virus merupakan sesuatu yang tidak dapat dilihat apalagi dirasakan oleh siapapun, kecuali bagi orang yang terjangkit virus tersebut. Namun, merupakan kewajiban orangtua untuk memastikan kesehatan dan keselamatan anak-anaknya.

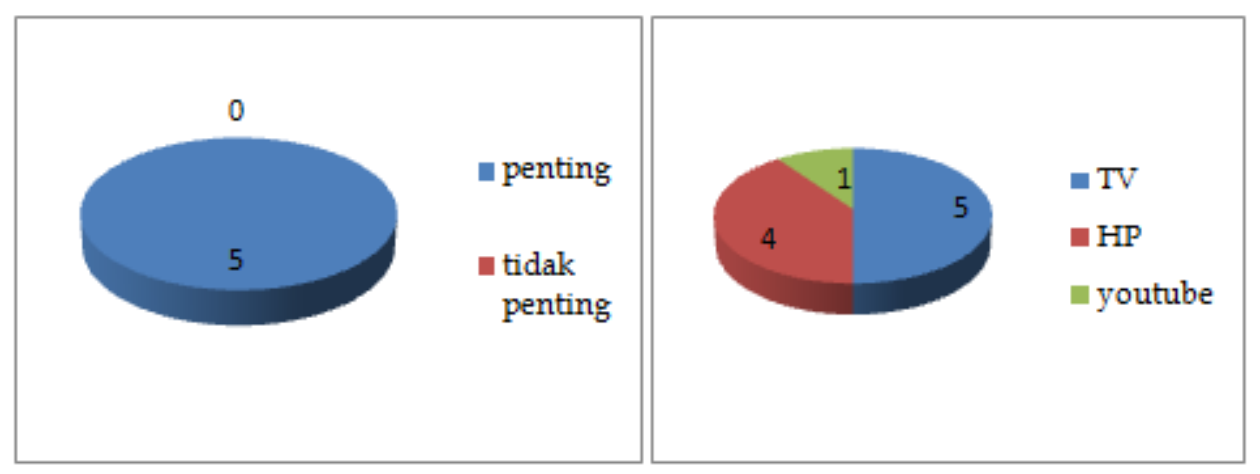

Gambar 4. Pentingnya menjelaskan virus corona pada anak (kiri); media yang digunakan untuk menjelaskan (kanan) 
Dari gambar 4, terlihat bahwa orangtua menjelaskan keadaan yang terjadi saat ini dengan memanfaatkan media seperti TV, HP, dan youtube. Ketiga media tersebut merupakan media yang cukup efektifdalam penyebaran informasi (Cahyono, 2016; Fatty Faiqah, . Muh. Nadjib, . Andi Subhan Amir, 2016; Hajar, 2018; Khatimah, 2018; Mulyana, 2002; Rohani, 2015)termasuk mengenai Covid-19. Selain disajikan dengan narasi yang mudah dipahami, ditampilkan pula gambar (youtube) atau kejadian sebenarnya (berita di TV) sehingga proses transfer informasi terjadi dengan mudah. Dengan mengajak anak menonton TV, HP, maupun youtube, orangtua dapat menjelaskan mengenai virus corona dan bahayanya. Melalui youtube, perhatian anak lebih mudah untuk didapatkan, rasa ingin tahu meningkat, demikian pula dengan daya ingatnya (Khoiriyati dan Saripah, 2018).Adanya pendampingan orangtua (Abtokhi, 2012)disertai dengan penggunaan bahasa yang baik (Gade, 2012)dalam menyampaikan informasi menjadi salah satu strategi yang dapat digunakan orangtua. Selain memberikan penjelasan, perilaku yang ditunjukkan orangtua di rumah, akan menjadi cara yang cukup efektif dalam mengenalkannya. Orangtua yang berulang kali mencuci tangan dengan sabun setelah beraktivitas, akan dilihat oleh anak dan kemudian akan diikutinya. Orangtua yang keluar rumah menggunakan masker, tentu akan pula diikuti oleh anak. Demikian pula jika orangtua berdiam diri di rumah dan melakukan banyak aktivitas menarik bersama dengan keluarga, tentu membuat anak merasa betah dan nyaman berada di rumah. Cara lain yang juga dapat digunakan adalah dengan mengajukan pertanyaan-pertanyaan sederhana seperti mengapa anak tidak boleh main di luar rumah, mengapa harus mencuci tangan(Hewi \& Asnawati, 2020), dan seterusnya. Usaha yang dilakukan tersebut merupakan upaya orangtua melindungi anak-anaknya agar kesehatan anak tetap terjaga (Marui, 1952).

Penggunan media-media tersebut juga dikarenakan tidak tersedianya media lain yang dapat digunakan untuk mengenalkan Covid-19 pada anak di rumah. Seperti misalnya buku cerita yang berisi mengenai informasi Covid-19. Ada, namun masih jarang ditemukan. PSBB yang berdampak pada ditutupnya toko-toko buku juga berakibat tidak mudahnya mendapatkan buku yang dimaksud. Demikian juga media dalam bentuk permainan belum dapat ditemukan. Sehingga media yang paling memungkinkan untuk mengenalkan Covid19 adalah melalui TV, HP, dan youtube.
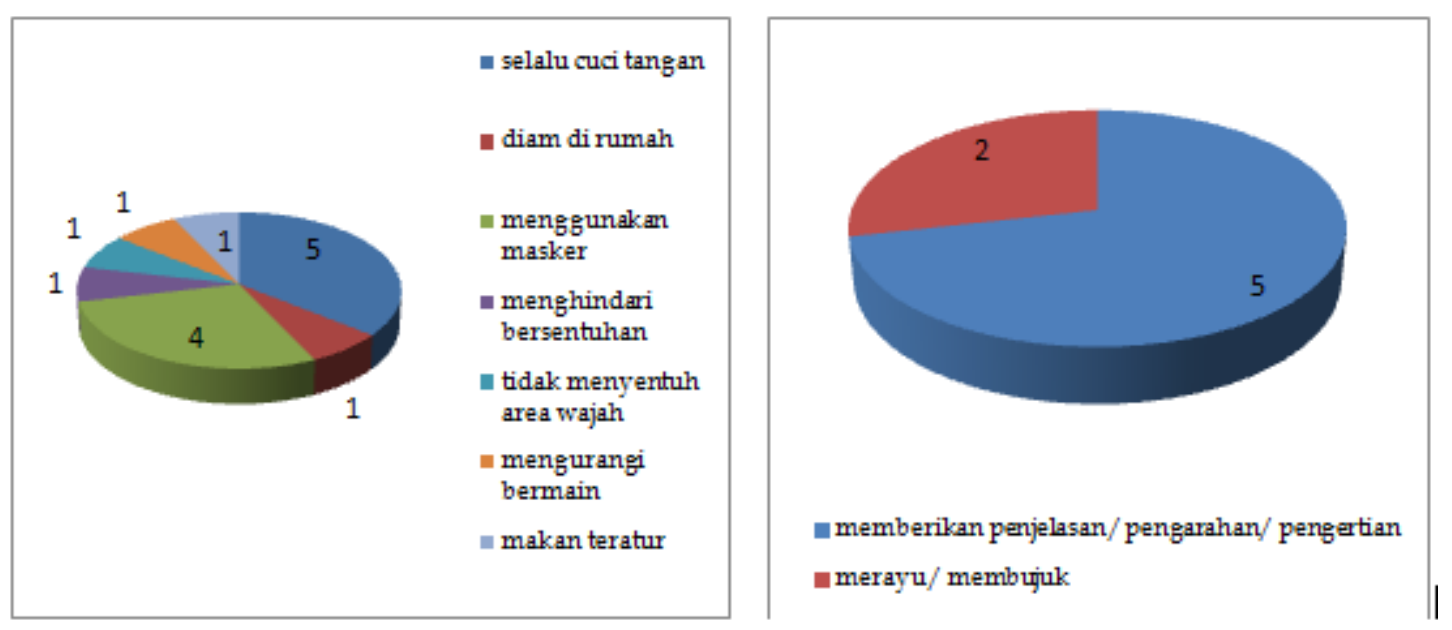

Gambar 5. Perilaku anak selama masa Covid-19(kiri); tindakan orangtua agar anak menjaga diri cari virus corona (kanan)

Hasil dari upaya pendidikan dan perlindungan orangtua kepada anak-anaknya adalah kesediaan anak untuk melakukan tindakan-tindakan yang diajarkan. Tindakan yang paling banyak dilakukan anak berdasarkan gambar 5 adalah selalu mencuci tangan dan menggunakan maskerketika keluar rumah.Hal tersebut tentu ia lakukan karena orangtuanya melakukan hal yang sama atau meminta anak melakukan hal tersebut. Artinya anak akan 
meniru apa yang anak lihat pada tindakan yang dilakukan orangtua, children always adopt parent's values and types of behavior(Kasapi dan Gjylymsere dalam (Marilena, 2015).

Namun, anak merupakan sosok yang aktif diiringi oleh rasa ingin tahu yang besar untuk mengeksplor berbagai hal yang ada di lingkungannya. Keadaan yang terjadi saat ini terkadang tidak sepenuhnya dipahami oleh anak sehingga tetap ingin melakukan kegiatankegiatan yang ia sukai, yaitu bermain dengan teman-temannya di luar rumah. Sehingga terkadang anak menunjukkan penolakan untuk mengikuti aturan yang ada. Meskipun dilarang untuk beraktivitas di luar rumah, namun anak tetap bersikeras untuk melakukannya, tanpa menggunakan masker. Hal tersebut menuntut orangtua untuk dapat mengatasi permasalahan yang ada dan memberikan solusi namun tetap dapat memfasilitasi kebutuhan anak untuk bermain. Hal yang telah dilakukan orangtua yaitu dengan memberikan penjelasan/ pengarahan/ pengertian kepada anak akan kondisi yang saat ini sedang terjadi. Selain itu, orangtua juga berusaha untuk merayu atau membujuk anak agar mau melakukan aktivitasnya di rumah daripada bermain di luar. Hal tersebut dilakukan oleh 5 orang tua sedangkan 2 orangtua lainnya juga merayu atau membujuk anak-anaknya agar mau mengikuti aturan tersebut.Tidak mudah tentunya menenangkan anak yang menginginkan haknya untuk bermain. Sehingga dibutuhkan tidak hanya pengetahuan tetapi juga kemampuan untuk memperlakukan anak dengan baik sehingga makin memperkuat ikatan keluarga dan tetap mewujudkan perkembangan anak yang optimal (Matilov dan Naum dalam (Marui, 1952). Orangtua yang tidak dapat menenangkan anak dengan baik dan dengan cara-cara yang benar, hanya akan menimbulkan pertengkaran antara orangtua dengan anak yang tentunya akan berpengaruh pada banyak hal dalam aspek perkembangan anak. Usaha menenangkan anak yang dilakukan ibu merupakan suatu upaya perlindungan dalam aspek psikologis anak(Marui, 1952), sehingga larangan anak bermain di luar rumah dapat diterima secara nalar oleh anak dan keberadaan anak di rumah tetap dapat menyenangkan.

Namun, dua hal penting yang tidak dilakukan anak adalah menghindari menyentuh mata, hidung, dan mulut; serta menutup mulut dan hidung saat batuk atau bersin. Hal ini seharusnya juga diajarkan orangtua mengingat sifat aktif anak dalam mengeksplor lingkungan yang salah satunya adalah dengan cara memegang benda atau apapun yang ada. Meskipun anak telah diberitahu bahkan selalu diingatkan untuk mencuci tangan, akan lebih baik lagi apabila orangtua juga menjelaskan perlunya anak menghindari tiga wilayah tersebut. Demikian pula ketika anak batuk atau bersin. Anak diminta tidak hanya menghindar dari orang yang sedang batuk tetapi juga harus menjaga kesehatan orang lain dengan menutup mulut dan hidungnya ketika bersin, karena virus corona dapat menyebar melalui percikan air yang keluar dari mulut ataupun hidung(Indonesia, 2020).

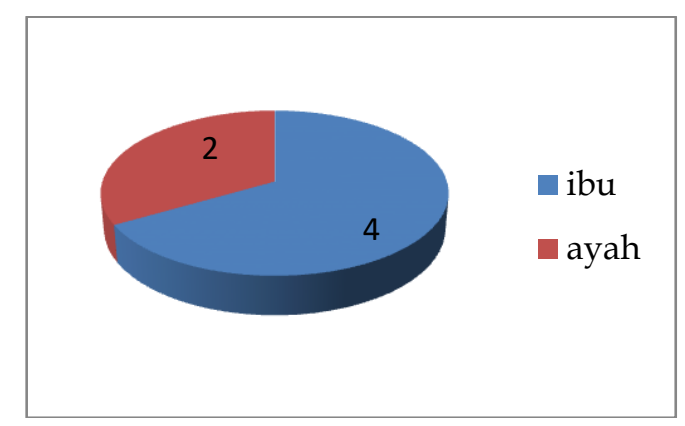

\section{Gambar 6. Peran dominan mengenalkan virus corona pada anak}

Seharusnya mendidik anak termasuk mengenalkan Covid-19 dilakukan oleh ayah dan ibu, selaku orangtua.Namun, berdasarkan gambar 6 diketahui bahwa orangtua yang berperan secara dominan adalah ibu yaitu sebanyak 4 keluarga, dan ayah sebanyak 2 keluarga.Artinya, ada keluarga yang ibu lebih berperan dalam mengenalkan Covid-19 (3 
keluarga), ayah lebih berperan dibanding ibu (1 keluarga), dan satu keluarga dimana antara ayah dan ibu saling bekerjasama untuk mengenalkan Covid-19 pada anak.Meskipun ibu melaksanakan perannya dengan baik, namun dukungan dari ayah tentu sangat diperlukan. Seperti halnya peran ayah dalam membiasakan anak mencuci tangan (Hastuti et al., 2011; Rihiantoro \& Jurusan Keperawatan Poltekkes Tanjungkarang, 2016). Kewajiban memberikan pendidikan dan perlindungan tidak semata tugas seorang ibu, tetapi juga ayah ( $R$ \& R, 2010). Ayah dan ibu harus memiliki pengetahuan dan pemahaman yang sama terutama terkait kondisi yang terjadi saat ini. Kerjasama diperlukan agar anak tidak memiliki kebingungan karena muncul perspektif yang berbeda pada kedua orangtuanya. Orangtua harus dapat memenuhi semua kebutuhan anak, baik pendidikan, perawatan, maupun kasih sayang dimana anak tidak bisa mendapatkannya di luar rumah sebagai akibat adanya wabah virus corona.

Adanya pemahaman yang diberikan orangtua, baik ayah maupun ibu, mengenai kondisi yang terjadi saat ini dapat membuat anak memiliki rasa peduli, empati, serta kasih sayang terhadap sesama, termasuk kasih sayang terhadap dirinya sendiri (Marui, 1952), dan keluarganya. Meskipun dijelaskan bahwa apabila ibu dapat menjalankan perannya dengan baik, maka anak akan memiliki konsep diri yang baik (Pangesti \& Agussafutri, 2017), namun keterlibatan ayah dalam pengasuhan dan pendidikan anak terutama dimasa pandemik, akan membuat anak semakin lekat dengan ayahnya, merasa aman, dan pada akhirnya anak dapat tumbuh dengan baik secara psikososial. Di sisi lain telah pula dijelaskan bahwa masa usia prasekolah adalah masa yang penting dalam pembentukan kepribadian, emosi, dan kesejahteraan anak. Dan hal tersebut dapat terjadi apabila tercipta hubungan yang baik antara anak dengan orangtua serta kemampuan orangtua melaksanakan peran dan fungsinya dengan baik (Vasilyeva \& Shcherbakov, 2016), selama anak berada di rumah.

\section{SIMPULAN}

Simpulan dari penelitian ini adalah bahwa orangtuatelah melaksanakan perannya dalam mengenalkan Covid-19 menggunakan media TV, HP dan youtube; menjadi contoh dalam tindakan pencegahan;serta mengajarkan berbagai tindakan pencegahan dengan pendampingan, penjelasan, serta bujukan dan rayuan terutama bagi anak yang sulit untuk melaksanakan tindakan perlindungan diri dari Covid-19. Namun, pengenalan Covid-19 lebih banyak dilakukan ibu dibandingkan ayah. Sehingga diperlukan kerjasama dan peran ayah untuk mendukung dan melengkapi usaha yang dilakukan ibu dalam mengenalkan Covid-19 kepada anak.

\section{UCAPAN TERIMA KASIH}

Terimakasih disampaikan kepada 5 keluarga di wilayah RT 006 RW 07 Perum II Tangerang, Banten, yang berkenan memberikan informasi mengenai pengetahuan serta usaha yang dilakukan untuk mengenalkan Covid-19 serta pencegahannya kepada anak.

\section{DAFTAR PUSTAKA}

Abtokhi, A. (2012). Peran Ibu dalam Kegiatan Pendampingan Belajar Anak melalui Prinsip Individual Learning-Centered. Egalita, 4(2), 168-177. https:// doi.org/10.18860/egalita.v0i0.1993

Aisyah, D. S., Riana, N., \& Putri, F. E. (2019). Peran Ayah (Fathering) Dalam Perkembangan Sosial Anak Usia Dini (Studi Kasus pada Anak Usia 5-6 tahun di RA Nurhalim Tahun Pelajaran 2018). Jurnal Wahana Karay Ilmiah_Pascasarjana (S2) PAI Unsika, 3(1), 294304.

Bungin, B. (2011). Penelitian Kualitatif: Komunikasi, Ekonomi, Kebijakan Publik, Dan Ilmu Sosial Lainnya. In Kencana (kedua). https:/ / doi.org/10.1002/jcc.21776

Cahyono, A. S. (2016). Pengaruh Media Sosial Terhadap Perubahan Sosial Masyarakat di 
Indonesia. Jurnal Publiciana, 9(140-157), 140-157.

Cnnindonesia. (2020). Update Corona 30 April: 10.118 Positif, 792 Meninggal Dunia.

Fatty Faiqah, . Muh. Nadjib, . Andi Subhan Amir, . (2016). Youtube Sebagai Sarana Komunikasi bagi Komunitas Makassarvidgram. Jurnal Komunikasi KAREBA, 5(2), 259-272. https://doi.org/10.1080/14639947.2015.1006801

Gade, F. (2012). Ibu Sebagai Madrasah dalam Pendidikan Anak. Jurnal Ilmiah Didaktika, 13(1), 31-40. https://doi.org/10.22373/jid.v13i1.462

Hadi, A. (2016). Nilai-nilai Pendidikan Keluarga dalam UU No.23 Tahun 2002 Tentang Perlindungan Anak. An-Nisa, 9(2), 101-121.

Hajar, I. (2018). Youtube sebagai Sarana Komunikasi Dakwah di Kota Makasar. Jurnal AlKhitabah, 2(2), 95-109.

Hastuti, E. P., Aisah, S., \& Santosa, B. (2011). Hubungan Peran Orang Tua Dengan Kebiasaan Mencuci Tangan Pada Anak Prasekolah Di Taman Kanak-Kanak Siwi Peni Guntur Demak. Fikkes Jurnal Keperawatan, 4(2), 106-120.

Hewi, L., \& Asnawati, L. (2020). Strategi Pendidik Anak Usia Dini Era Covid-19 dalam Menumbuhkan Kemampuan Berfikir Logis. Jurnal Obsesi : Jurnal Pendidikan Anak Usia Dini, 5(1), 158. https://doi.org/10.31004/obsesi.v5i1.530

Hidayati, F., Kaloeti, D. V. S., \& Karyono. (2011). Peran Ayah Dalam Pengasuhan Anak. Peran Ayah Dalam Pengasuhan Anak, 9(1), 1-10. https:// doi.org/10.14710/jpu.9.1

Indonesia, K. K. R. (2020). Pedoman Pencegahan dan Pengendalian Corona Virus Diseas (COVID19). Jakarta, Indonesia.

Jailani, M. S. (2014). Teori Pendidikan Keluarga dan Tanggung Jawab Orang Tua dalam $\begin{array}{llll}\text { Pendidikan Anak Usia Dini. Nadwa, } 245 . & \end{array}$ https://doi.org/10.21580/nw.2014.8.2.580

Jakarta, D. P. P. D. (2020). Surat Edaran No. 33/ 2020 Tentang Pembelajaran Jarak Jauh (PJJ)/ Home Learning Bermakna dan Menyenangkan. Jakarta.

Khatimah, H. (2018). Posisi dan Peran Media dalam Kehidupan Masyarakat. Tasamuh, 16(1), 119-138. https:/ / doi.org/10.20414/tasamuh.v16i1.548

Khoiriyati, S., \& Saripah, S. (2018). Pengaruh Media Sosial pada Perkembangan Kecerdasan Kognitif Anak Usia Dini. Aulada: Jurnal Pendidikan Dan Perkembangan Anak, 1(1), 4960. https:// doi.org/10.31538/aulada.v1i1.209

Kosegeran, H., Ismanto, A., \& Babakal, A. (2013). Hubungan Tingkat Pengetahuan Orang Tua tentang Stimulasi Dini dengan Perkembangan Anak Usia 4-5 Tahun di Desa Ranoketang Atas. Jurnal Keperawatan UNSRAT, 1(1), 112269.

Lestari sri. (2018). Psikologi Keluarga:Penanaman Nilai dan Penanganan Konflik Dalam Keluarga (1st ed.). Jakarta: Kencana Prenada Media Grup.

Lismanda, Y. F. (2017). Pondasi Perkembangan Psikososial Anak Melalui Peran Ayah Dalam Keluarga. Vicratina: Jurnal Pendidikan Islam, 2(2), 89-98.

Marilena, T. (2015). The Role of Parents in Integrating their Own Children in Society. Procedia - Social and Behavioral Sciences, 180, 1680-1685. https://doi.org/10.1016/j.sbspro.2015.05.067

Marui, K. (1952). The Role of Parents in the Education of Children. Psychiatry and Clinical Neurosciences, 6(3), 221-230. https://doi.org/10.1111/j.1440-1819.1952.tb01331.x

Mujianto, H. (2019). Pemanfaatan Youtube Sebagai Media Ajar Dalam Meningkatkan Minat Dan Motivasi Belajar. Jurnal Komunikasi Universitas Garut, 5(1), 135-159. https://doi.org/10.10358/Jk.V5i1.588

Mulyana, D. (2002). Pengaruh Terpaan Informasi Kesehatan di Televisi terhadap Sikap Hidup Sehat Keluarga. Jurnal Komunikasi Mediator, 3(2), 309-322. https:// doi.org/10.29313/mediator.v3i2.779

Palupi, I. D. R. (2020). Pengaruh Media Sosial Pada Perkembangan Kecerdasan Anak Usia Dini. Jurnal Edukasi Non Formal, 1(2), 127-134. https://doi.org/10.31538/aulada.v1i1.209 
Pangesti, C. B., \& Agussafutri, W. D. (2017). Hubungan Peran Ibu dengan Konsep Diri Anak Usia 3-5 Tahun. Jurnal Kesehatan Kusuma Husada, 8(2), 160-165. https:// doi.org/10.34035/jk.v8i2.236

Putra, C. A. (2017). Pemanfaatan Teknologi Gadget Sebagai Media Pembelajaran. Bitnet: $\begin{array}{llll}\text { Jurnal Pendidikan Teknologi Informasi, 2(2), } & \text { 10. }\end{array}$ https:// doi.org/10.33084/bitnet.v2i2.752

R, J., \& R, L. (2010). Keperawatan keluarga : plus contoh askep keluarga. Jogyakarta: Nuha Medika.

Rihiantoro, T., \& Jurusan Keperawatan Poltekkes Tanjungkarang, D. (2016). Peran Orang Tua Dalam Kebiasaan Mencuci Tangan Pada Anak Usia 6-8 Tahun. In Jurnal Keperawatan. https://doi.org/10.26630/Jkep.V12i1.377

Rohani, G. A. (2015). Pengaruh Televisi (TV) Terhadap Aspek-Aspek Perkembangan Anak Usia 3-4 Tahun. Jurnal Pendidikan Anak, 4(2). https:/ / doi.org/10.21831/jpa.v4i2.12355

Utomo, A. P. (2020, March). WHO Umumkan Virus Corona sebagai Pandemi Global. Kompas.

Vasilyeva, E. N., \& Shcherbakov, A. V. (2016). Parental Roles and Types of Parentings as Determinants of a Preschooler's Emotional and Personal Well-being. Procedia - Social and Behavioral Sciences, 233, 144-149. https:// doi.org/10.1016/j.sbspro.2016.10.172

World Health Organization. (2020). Coronavirus disease 2019. Retrieved June 13, 2020, from World Health Organization website: https://www.who.int/emergencies/diseases/novel-coronavirus-2019

Wulandari, R. D., \& Pertiwi, E. W. (2018). Pengetahuan dan Peran Orang Tua terhadap Perilaku Hidup Bersih dan Sehat pada Siswa SD di Kecamatan Kramatwatu Serang. Jurnal Dunia Kesmas, 7(4), 225-232. https:/ / doi.org/10.1017/CBO9781107415324.004 